\title{
SENSITIVITY OF RABBIT FIBROCHONDROCYTES TO MYCOPLASMAS
}

\author{
Carlos Manuel de Oliveira Nascimento ${ }^{1}$; Cristina Adelaide Figueiredo² Jorge Timenetsky $^{1 *}$ \\ ${ }^{1}$ Departamento de Microbiologia, Instituto de Ciências Biomédicas da Universidade de São Paulo, São Paulo, SP, Brasil; \\ ${ }^{2}$ Setor de Vírus Exantemáticos, Instituto Adolfo Lutz, São Paulo, SP, Brasil
}

Submitted: March 01, 2002; Returned to authors for corrections: June 18, 2002; Approved: September 24, 2002

\section{SHORT COMMUNICATION}

\begin{abstract}
Primary cell culture from rabbit meniscus (fibrochondrocytes-FcrC) was infected for 24 hours with different inocula ( $10^{2}$ to $10^{7}$ Colony Forming Units-CFU) of Mycoplasma hominis PG-21, M. pneumoniae FH and 1428 or M. arthritidis PG-6. The severity of the different obtained cytophatic effects-CPE was inoculum, Mycoplasma species and strain dependant. These bacteria were recovered from all infected FcrC and the SP4 medium for mycoplasmas also caused toxic effect on the FcrC. It was concluded that rabbit fibrochondrocytes were sensitive to mycoplasma infection, as well as to the SP4 mycoplasma medium.
\end{abstract}

Key words: Mycoplasma, fibrochondrocytes, arthritis.

Mycoplasmas have between 200 to 400nm, lack the cell wall, self-replicate, are wide spread in nature and may cause diseases. Some biologic features of these bacteria explain partially their role in hosts. Many cytogenetic effects have been described in cell cultures infected accidentally or experimentally with mycoplasmas. Meantime the mycoplasmas can stress the infected cell and may not kill it. Although this infection in cell culture invalidates some laboratory results, still cell cultures are useful and important tools to study the biology of mycoplasmas and to minimize the use of experimental animals $(6,8)$.

In humans Mycoplasma pneumoniae is a well-documented respiratory pathogen. However, species from normal flora of oral or urogenital tract may cause usual or unusual infections but rarely cause death. Septic arthritis by mycoplasmas in humans is unusual and hypogamaglobulinaemia is almost always present (2).

$M$. arthritidis is a natural arthrogenic species in rodents and produces joint disease by intravenous inoculation (15). However, the species isolated from human synovial fluids produce a similar disease in chimpanzee if inoculated intraarticularly but not intravenously $(1,13)$. The arthrogenicity of mycoplasmas, remains unknown in humans. M. hominis is the most frequent species recovered from synovial fluids. However, M. pneumoniae, M. salivarium, M. fermentans and $U$. urealyticum have also been isolated. (11).

Despite of the known effects of mycoplasmas on cell cultures and the joint disease caused by them in humans it was proposed to use as a choice the rabbit meniscus cell culture (16) in order to verify this cell sensitivity to $M$. hominis, $M$. pneumoniae and M. arthritidis. Mycoplasma hominis PG-21, M. hominis 1620 (synovial fluid isolate), M. pneumoniae-FH, M. pneumoniae 1428 (nasopharynx isolate) and $M$. arthritidis PG-6 were cultured in $100 \mathrm{~mL}$ of SP4 broth. Cultures were separated in aliquots of $1.0 \mathrm{~mL}$, stored at $-70^{\circ} \mathrm{C}$ and quantified for determination of Colony Forming Units-CFU after freezing (8). Fibrochondrocytes culture-FcrC was obtained from the meniscuses of knees (lateral and medial) of New Zealand rabbits with 120 day-old weighting between 1.5 and $2.0 \mathrm{Kg}$. The tissue was removed and washed in PBS pH 7.5 with $40 \mathrm{mg} / \mathrm{mL}$ of gentamicin. Soon after it was transferred to a Minimum Essential Medium of Eagle, modified by Dulbecco (DMEM) in balanced saline

\footnotetext{
* Corresponding author. Mailing address: Departamento de Microbiologia, ICB II, USP. Av. Prof. Lineu Prestes, 1374, Cidade Universitária, 05508900, São Paulo, SP, Brasil. Tel.: (+5511) 3091-7297, Fax: (+5511) 3091-7354. E-mail: jtimenet@icb.usp.br
} 
solution of Earle (GIBCO), without sulfate, supplemented with $10 \%$ of inactivated Fetal Bovine Serum-FBS. After 24 hours, the meniscuses were fragmented in $0.3 \times 0.3 \mathrm{~cm}$ and washed twice in DMEM. The suspension was incubated at $37^{\circ} \mathrm{C}$ in $10 \mathrm{~mL}$ of DMEM with $2 \mathrm{mg} / \mathrm{mL}$ of colagenase type I and filtered through nylon membrane to remove non-homogenized fragments. The suspension was washed twice in DMEM, transferred to a solution of DMEM (without antibiotic) and $10 \%$ of FBS and inoculated at $10^{5} \mathrm{cells} / \mathrm{cm}^{2}$ in 35 mm Petri dishes. The cellular viability was quantified by exclusion of Trypan Blue. Cultures were incubated at $37^{\circ} \mathrm{C}$ with $5 \%$ of $\mathrm{CO}_{2}$ and monitored for the sterility $(5,16)$.

Washed suspensions of mycoplasmas, at $10^{2}$ to $10^{7} \mathrm{CFU} / \mathrm{mL}$ in DMEM were obtained, and one milliliter of each suspension was inoculated, in triplicate, on FcrC monolayer, in microplates with 24 wells. Series of wells containing only FcrC, mycoplasma or DMEM medium were used as controls. FcrC inoculated or not with mycoplasmas, were fixed with $1.0 \%$ of glutaraldehyde in sodium and potassium phosphate $0.15 \mathrm{M}, \mathrm{pH}$ 7.2 solution, stained with $1 \%$ toluidine blue $\mathrm{pH} 3.5$ and observed under light microscope at 100X magnification.

The representative cytophatic effects-CPE are shown in Fig. 1. A monolayer with spindle-shaped fibrochondrocytes was obtained after eight days and the FcrC was stable for 16 days (Fig. 1a). The inoculation of sterile SP4 broth without, penicillin or thallium acetate caused intense cell damage of FcrC after 24 hours (Fig. 1b).

M. hominis PG-21 inoculated at $10^{2} \mathrm{CFU}$ caused a weak CPE on FcrC. The isolate 1620 at $10^{2}$ (Fig. 1c) and $10^{3} \mathrm{CFU}$ produced similar result than PG-21 strain. Inocula of $10^{4}$ to $10^{7} \mathrm{CFU}$ caused a more intensive CPE but without damage of the monolayer. However, when suspended at $10^{7} \mathrm{CFU} / \mathrm{mL}$, caused a higher CPE than PG-21 (Fig. 1d).

M. pneumoniae caused different CPE on FcrC than $M$. hominis. The CPE on FcrC with M. pneumoniae $\mathrm{FH}$ and 1428 (Fig. 1e) were similar at $10^{2} \mathrm{CFU}$. However at $10^{7} \mathrm{CFU}$ the isolate 1428 caused more intense CPE (Fig. 1f).
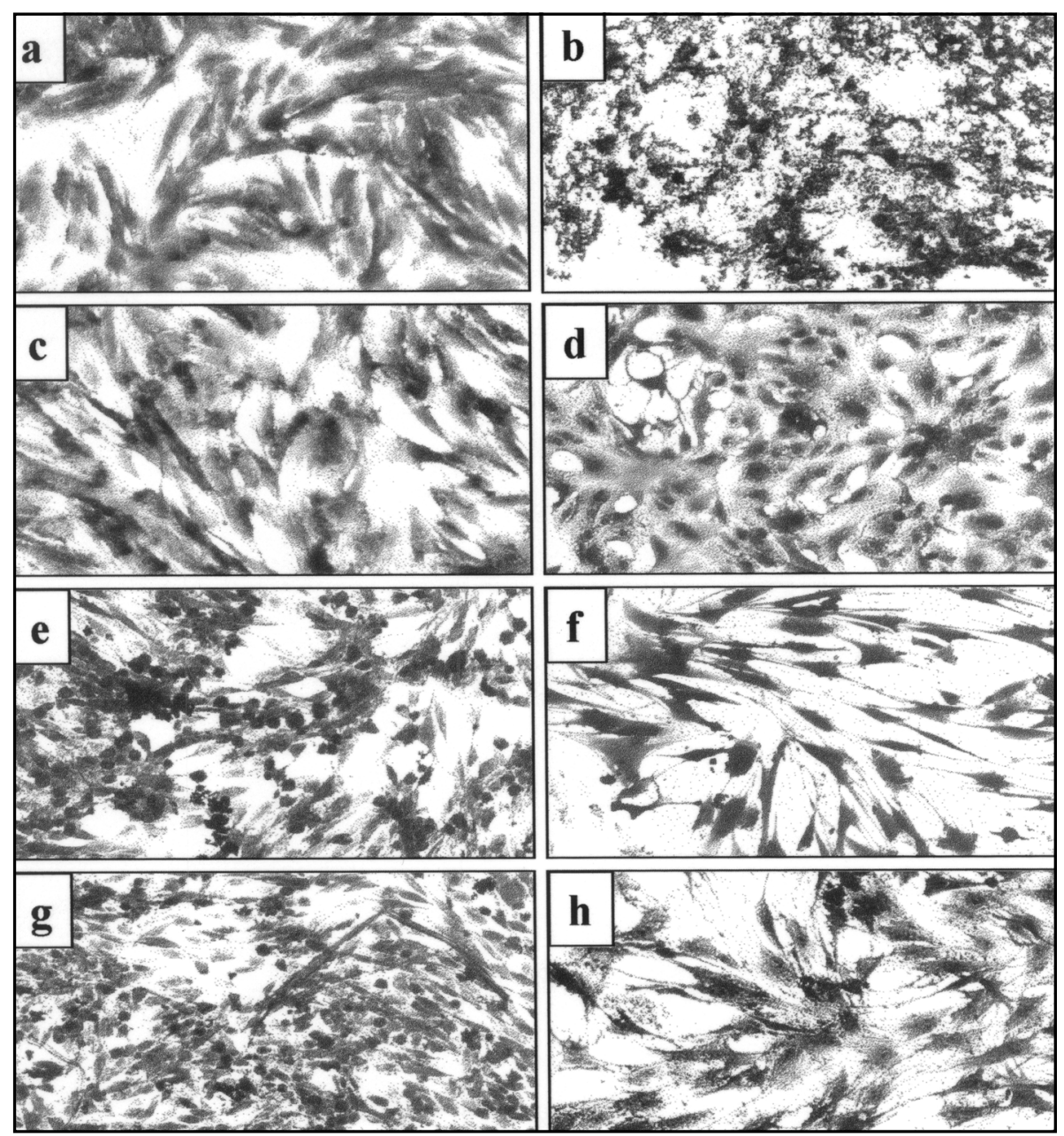

Figure 1. Cytophatic effects of fibrochondrocyte culture infected with mycoplasmas after 24 hours (X 100).

a - Non infected FcrC (control);

b- FcrC inoculated with SP4 (mycoplasma broth).

Infection with $10^{2}$ and $10^{7} \mathrm{CFU}$ from left to right

c/d - FcrC infected with M. hominis-1620;

e/f - FcrC infected with M. pneumoniae-1428;

g/h - FcrC infected with M. arthritidis-PG6.
M. arthritidis also induced CPE on $\mathrm{FcrC}$ with $10^{2}$ to $10^{7} \mathrm{CFU}$ (Fig. $1 \mathrm{~g}$ and 1f). The CPE of FcrC with higher inocula of $M$. arthritidis were similar to the CPE caused by M. pneumoniae.

The studied mycoplasmas were recovered in SP4 broth from all infected FcrC. After 24 hours it was recovered about $10^{3}$ to $10^{6} \mathrm{CFU}$ of Mycoplasma from the respective supernatants in SP4 agar, from the initial infected cells with $10^{4}$ to $10^{7} \mathrm{CFU}$ of Mycoplasma. Non-infected FcrC with or without $\mathrm{pH}$ changing after 24 hours were negative for bacterial culture.

Rabbit cartilage cells have been suggested to study the arthrogenicity of mycoplasmas from rodents and humans (15). 
$M$ arthritidis produces superantigen MAM, shares membrane antigens with rat or human chondrocytes and produce immunocomplexes. Reactive $\mathrm{T}$ cells lines to this mycoplasma also responded to syngeneic chondrocytes. This species does not attach to several types of mammalian cells but it is able to adhere to synovial fibroblasts, lung and skin cells $(3,10,14)$. Adhesion is an initial event during mycoplasma colonization and the disease also depends on host parasite interaction (2). Invasion has been documented for other Mycoplasma species in leukocytes or other cells (7). M. pneumoniae, M. pulmonis and $M$. arthritidis were inoculated intrarticularly in rabbits into, their joints and $M$. arthritidis was not be recovered from respective synovial fluids (4).

This study showed that the infection of $10^{2} \mathrm{CFU}$ of $M$. hominis, M. arthritidis and M. pneumoniae caused CPE on rabbit FcrC after 24 hours. The cells remained active during mycoplasma infection because the DMEM broth became acid in all inocula and $M$. hominis and M. arthritidis make the medium to become alkaline in presence of arginine. Mycoplasmas usually did not reach satisfactory growth in SP4 broth after 24 hours, but caused $\mathrm{CPE}$ on FcrC. The activity of fibrochondrocytes was not confirmed after M. pneumoniae infection because this species metabolize glucose and acidify the medium. Depletion of arginine or glucose interferes differently on cells, but non-metabolic features of mycoplasmas also cause CPE (6).

The decrease of CFU after 24 hours probably occurred because mycoplasmas could attach to fibrochondrocytes or because they lost their viability in FcrC. In fact the included species have been reported to adhere to other mammalian cells (7). The intense and rapid toxicity of sterile SP4 on FcrC should be considered for further studies.

Cell responses after two to 24 hours of mycoplasma infection have been cited before and inocula of about $10^{2}$ to $10^{8} \mathrm{CFU}$ have been used for acute and chronic infections to other mycoplasmas $(2,7)$.

The more intense $\mathrm{CPE}$ was obtained on $\mathrm{FcrC}$ with $10^{7}$ rather than with $10^{2} \mathrm{CFU}$, which is in accordance with the literature in the relation to other mycoplasmas and cell cultures. There are few reports regarding the use of low inoculum. By the other side, no CPE was observed in some accidentally infected cell cultures with $10^{8} \mathrm{CFU} / \mathrm{mL}$ of mycoplasma (9).

M. hominis is a common urogenital species of human origin, and the isolate 1620 was recovered in about $10^{7} \mathrm{CFU} / \mathrm{mL}$ from human synovial fluid of a patient with hypogamaglobulinaemia (12). This isolate caused a more severe disease than the reference strain PG-21 when inoculated in chimpanzee (1). In fact, the clinical isolate 1620 induced more severe CPE on FcrC than the reference strain PG-21 when inoculated with higher inocula. Figures 1a (control) and 1c shows similar CPE of FcrC, but the infected FcrC has the nuclei more intensely stained. This is also in accordance with literature that the mycoplasma infection in cell cultures may be slight and do not noted.
M. arthritidis was included in this study as a control because it is a known arthrogenic species in rodents (15). $M$. pneumoniae and $M$. arthritidis induced similar CPE and $M$. hominis induced different CPE. According to the literature the intraarticular infection in chimpanzee with $M$. hominis induced a more severe disease than M. pneumoniae (1). Mycoplasma inoculum size and the strain or isolate influenced the CPE on $\mathrm{FCrC}$ in the present study. The sensivity of FcrC to mycoplasmas may related to the differences among mycoplasmas.

Literature data show choices to control infections of mycoplasmas in cell cultures. New horizons have been openned up recently in Mycoplasmology including coinfections with other infectious agents (2).

\section{RESUMO}

\section{Sensibilidade de fibrocondrócitos de coelhos a micoplasmas}

Cultura primária de menisco de coelho (FibrocondrócitoFcrC) foi infectada por 24 horas com diferentes inóculos $\left(10^{2}\right.$ to $10^{7}$ Unidade Formadoras de Colonias-UFC) de Mycoplasma hominis PG-21, M. pneumoniae FHe 1428 ou M. arthritidis PG6. A severidade dos diferentes efeitos citopáticos-EC foram dependentes do inóculo, espécie e cepa de micoplasma. Estas bactérias foram reisoladas de todos os FcrC infectados e o meio SP4 para micoplasmas também causou efeito tóxico para os FcrC. Concluiu-se que os fibrocondrócitos de coelho foram sensíveis à infecção por micoplasmas e também ao meio SP4.

Palavras-chave: Micoplasma, fibrocondrócitos, artrite.

\section{REFERENCES}

1. Barile, M.F.; Kapatais-Zoumbos, K.; Grabowski, M.W.; Sneller, M.; Miller, L.; Chandler, D.K. Experimentally induced septic arthritis in chimpanzees infected with Mycoplasma hominis, Mycoplasma pneumoniae, and Ureaplasma urealyticum. Clin. Infect. Dis., 18(5): 694-703, 1994

2. Baseman, J.B.; Tully, J.G. Mycoplasmas: sophisticated, reemerging, and burdened by their notoriety. Emerg. Infect. Dis., 3: 21-32, 1997.

3. Bushe, K.; Schlesier, M.; Runge, M.; Binder, A.; Kirchoff, H. T cells responding to Mycoplasma arthritidis and chondrocytes in the infection of rats. Immunobiology, 181: 398-405, 1990.

4. Cedilho, L.; Gi, C.; Mayagoitia, C.; Cuellar, Y.; Yanez, A. Experimental arthritis induced by Mycoplasma pneumoniae in rabbits. J. Rheum., 19: 344-347, 1992.

5. Figueiredo, C.A.; Joazeiro, P.P.; Correa, O.M.T.; Araujo, V.C. In vitro rapid organization of rabbit meniscus fibrochondrocytes into chondro-like tissues structures (1999). In: XVII Congresso da Sociedade Brasileira de Microscopia e Microanálise e X Congresso da Sociedade Brasileira de Biologia Celular, Santos/ SP-Brazil.

6. McGarrity, G.J.; Kotani, H.; Butler, G.H. Mycoplasmas and tissue culture cells. In: Maniloff J, McElhaney RN, Finch LR \& Baseman JB (Editors). Mycoplasmas: Molecular Biology and Pathogenesis. ASM Press, Washington, DC.USA., 1992, p.445-454. 
7. Razin, S.; Yoga, D.; NATO, Y. Molecular biology and pathogenicity of mycoplasmas. Microbiol. Mol. Biol. Rev., 62: 1094-1156, 1998.

8. Rodwell, A.W.; Whitcomb, R.F. Methods for direct and indirect measurement ln: Razin S \& Tully JG (Editors). Methods in Mycoplasmology. Vol.1, Academic Press, New York, USA., 1985, p.185-196.

9. Rottem, S.; Barile, M.F. Beware of Mycoplasmas. TIBTECH., 11: 143-151, 1993.

10. Runge, M.; Binder, A.; Gurr, E.; Fischer, M.; Meier, J.; Kirchoff, H. Epitope sharing between Mycoplasma arthritidis and chondrocytes demonstrated by monoclonal antibodies Zentbl. Bakteriol., 273: 531538, 1990.

11. Schaeverbeke, T.; Vernhes, J.P.; Lequen, L.; Bannwarth, B.; Bebear, C.; Dehais, J. Mycoplasmas and arthritides. Rev. Rheum., (Engl. Ed), 64: 120-128, 1997.
12. Sneller, M.; Welborne, F.; Barile, M.F.; Plotz, P. Prosthetic joint infection with Mycoplasma hominis (letter), J. lnfect. Dis., 153: 174-175, 1985.

13. Timenetsky, J.; Barile, M.F. Immune response of chimpanzees infected with human Mycoplasmas. Lab. Anim. Sci., 48: 62-68, 1998.

14. Washburn, L.R.; Hirsh, S.; Voelker, L.L. Mechanism of attachment of Mycoplasma arthritidis to host cells in vitro. Infect. Immun., 61: 2670-2680, 1993.

15. Washburn, L.R. Experimental models of arthritis. In: Tully, J.G. \& Razin, S. (Editors) Molecular and Diagnostic Procedures in Mycoplasmology. Vol.2, Academic Press, Inc. San Diego, CA.USA, 1996, p.349-359.

16. Webber, R.J.; Zitaglio, T. JR. H.J.A. In vitro cell proliferation and protean synthesis of rabbit meniscal fibrochondrocytes as a function of age sex. Arthr. Rheum., 29: 1010-1016, 1986. 